\title{
PENANGKAPAN TUNA DENGAN MENGGUNAKAN KAPAL RISET M. V. SEAFDEC DI PERAIRAN SAMUDERA HINDIA
}

\author{
Budi Nugraha*) dan Erfind Nurdin*" \\ Peneliti pada Balai Riset Perikanan Laut, Muara Baru-Jakarta
}

\begin{abstract}
ABSTRAK
Tuna merupakan jenis ikan peruaya jauh (highly migratory species) dan hidup bergerombolan. Tuna long line dan tuna purse seine merupakan alat tangkap yang sangat efektif digunakan terutama untuk menangkap tuna di perairan terbuka atau samudera. Tulisan ini memberikan data dan informasi mengenai kegiatan penangkapan tuna dengan kapal riset M. V. SEAFDEC milik SEAFDEC Thailand pada bulan Desember 2004 di perairan Samudera Hindia sebelah barat Sumatera dengan menggunakan alat tangkap tuna long line dan tuna purse seine. Hasil tangkapan tuna long line didominasi oleh swordfish, diikuti oleh bigeye tuna dan yellowfin tuna, sedangkan hasil tangkapan tuna purse seine didominasi oleh skipjack tuna, diikuti oleh bigeye tuna, yellowfin tuna, dan ikan lain (by catch). Kisaran panjang cagak (FL) swordfish yang tertangkap dengan tuna long line antara 98 sampai dengan $209 \mathrm{~cm}$, bigeye tuna antara 105 sampai dengan $141,5 \mathrm{~cm}$, dan yellowfin tuna antara 132 sampai dengan $142 \mathrm{~cm}$, sedangkan skipjack tuna yang tertangkap dengan tuna purse seine antara 27 sampai dengan $61 \mathrm{~cm}$, yellowfin tuna antara 30 sampai dengan $137 \mathrm{~cm}$, bigeye tuna 34 sampai dengan $71 \mathrm{~cm}$.
\end{abstract}

KATA KUNCl: long line, purse seine, penangkapan, tuna, Samudera Hindia

\section{PENDAHULUAN}

Tuna termasuk ke dalam famili Scombridae, sub famili Scombrinae, suku Thunnini yang di Indonesia terdiri atas Thunnus albacares, $T$. obesus, $T$. alalunga, T. maccoyii, T. tonggol, Katsuwonus pelamis, Euthynnus affinis, Auxis thazard, dan A. rochei. Berdasarkan pada ukuran, tuna dibagi dalam 2 kelompok yaitu spesies Thunnus dikelompokkan ke dalam tuna besar (large tuna), spesies Katsuwonus, Euthynnus dan Auxis ke dalam tuna kecil (small tuna).

Sumber daya tuna tersebar di seluruh perairan di dunia dan pada umumnya menghuni perairan tropis. Tuna merupakan jenis ikan peruaya jauh (highly migratory species) dan hidup bergerombol. Menurut Kleiber et al. (1987) dalam Gafa et al. (2004), tuna merupakan ikan yang berumur panjang (long lived) dan mempunyai fekunditas tinggi (highly fecund).

Eksploitasi terhadap sumber daya tuna banyak dilakukan dengan menggunakan alat tangkap rawai tuna (tuna long line), pukat cincin tuna (tuna purse seine), pancing ulur (hand line), huthate (pole and line), dan jaring insang hanyut (drift gill net). Tuna long line dan tuna purse seine merupakan alat tangkap yang sangat efektif digunakan terutama untuk menangkap tuna di perairan terbuka atau samudera. Tuna long line digunakan untuk menangkap tuna yang berukuran besar di lapisan perairan dalam (90 sampai dengan $290 \mathrm{~m}$ ), sedangkan tuna purse seine untuk menangkap tuna berukuran kecil seperti baby tuna dan cakalang di lapisan perairan permukaan. Berdasarkan pada kedalaman operasi, tuna long line dibagi menjadi 2, yaitu subsurface long line dengan target yellowfin tuna dan deep long line dengan sasaran bigeye tuna. Tuna purse seine dioperasikan pada siang hari dengan menggunakan rumpon yang berfungsi sebagai alat pengumpul ikan. Uktolseja (1987) dalam Diniah et al. (2001), mengatakan bahwa rumpon atau payaos dapat menjaga atau membantu cakalang tetap berada di lokasi pemasangan selama 340 hari.

Tulisan ini memberikan data dan informasi mengenai kegiatan penangkapan tuna dengan kapal riset M. V. SEAFDEC (1178 GT) milik SEAFDEC-Thailand pada bulan Desember $2004 \mathrm{di}$ perairan Samudera Hindia sebelah barat Sumatera dengan menggunakan alat tangkap tuna long line dan tuna purse seine.

\section{TUNA LONG LINE}

\section{Deskripsi Alat Tangkap}

Tuna long line atau di Indonesia dikenal dengan nama rawai tuna digolongkan ke dalam kelompok alat tangkap pancing (line fishing). Satu unit (basket) tuna long line terdiri atas pelampung (float) dan tali pelampung (float line), tali utama (main line) dengan sejumlah tali cabang (branch line) yang berpancing (hook). 
Main line dan branch line terbuat dari bahan monofilamen dengan masing-masing berdiameter 3 sampai dengan $4 \mathrm{~mm}$ dan $2 \mathrm{~mm}$. Panjang main line antar tali cabang $40 \mathrm{~m}$, sedangkan panjang branch line 13 sampai dengan $20 \mathrm{~m}$. Pelampung terbuat dari fiber dengan diameter $300 \mathrm{~mm}$. Tali pelampung mempunyai panjang $25 \mathrm{~m}$ dan terbuat dari bahan PE dengan diameter $6 \mathrm{~mm}$ (Gambar 1).

Pada penelitian ini, operasi penangkapan dilakukan 5 kali. Penurunan pancing (setting) dilakukan pada sore hari sampai dengan menjelang malam, yaitu sekitar pukul $18 .^{30}$ sampai dengan $19 .{ }^{45}$ dan penarikan pancing (hauling) dilakukan pada pagi hari sekitar pukul $06{ }^{00}$ sampai dengan $09 .^{00}$. Jumlah pancing yang digunakan pada setiap kali setting berbeda-beda. Setting ke-1 berjumlah 521, ke-2 525, ke-3 511, ke-4 537, dan ke-5 529 buah. Konfigurasi pancing yang digunakan adalah 8 dan 10. Pada setting ke-1 dan ke-2 menggunakan 10 buah pancing, sedangkan setting ke- 3 sampai dengan ke- 5 menggunakan 8 buah pancing. Kecepatan mesin setting sekitar 10,5 knot dan kecepatan kapal sekitar 8 knot. Umpan yang digunakan adalah layang (Decapterus spp.) dengan ukuran panjang antara 10 sampai dengan $15 \mathrm{~cm}$ atau 7 sampai dengan 8 buah per $\mathrm{kg}$.

\section{Daerah Penangkapan}

Daerah penangkapan (fishing ground) tuna long line terletak pada posisi geografis antara $05^{\circ} 41^{\prime} 81$ $07^{\circ} 28^{\prime} 7$ LS dan $87^{\circ} 50^{\prime} 37-89^{\circ} 53^{\prime} 3$ BT (Gambar 2).

\section{Komposisi Hasil Tangkapan}

Selama penelitian diperoleh hasil tangkapan 77 ekor, terdiri atas 28 ekor $(36,36 \%)$ sebagai hasil tangkapan utama (target species) dan 49 ekor $(63,64 \%)$ hasil tangkapan sampingan (by catch).

Hasil tangkapan utama didominasi oleh Xiphias gladius (swordfish) yaitu 16 ekor $(20,78 \%$ ) dengan rata-rata laju tangkap (hook rate) 0,61; kemudian Thunnus obesus (bigeye tuna) 9 ekor $(11,69 \%)$ dengan hook rate 0,34 , dan Thunnus albacares (yellowfin tuna) 3 ekor $(3,90 \%)$ dengan hook rate 0,11 . Kisaran panjang cagak (FL) swordfish antara 98 sampai dengan $209 \mathrm{~cm}$, bigeye tuna antara 105 sampai dengan $141,5 \mathrm{~cm}$ dan yellowfin tuna antara
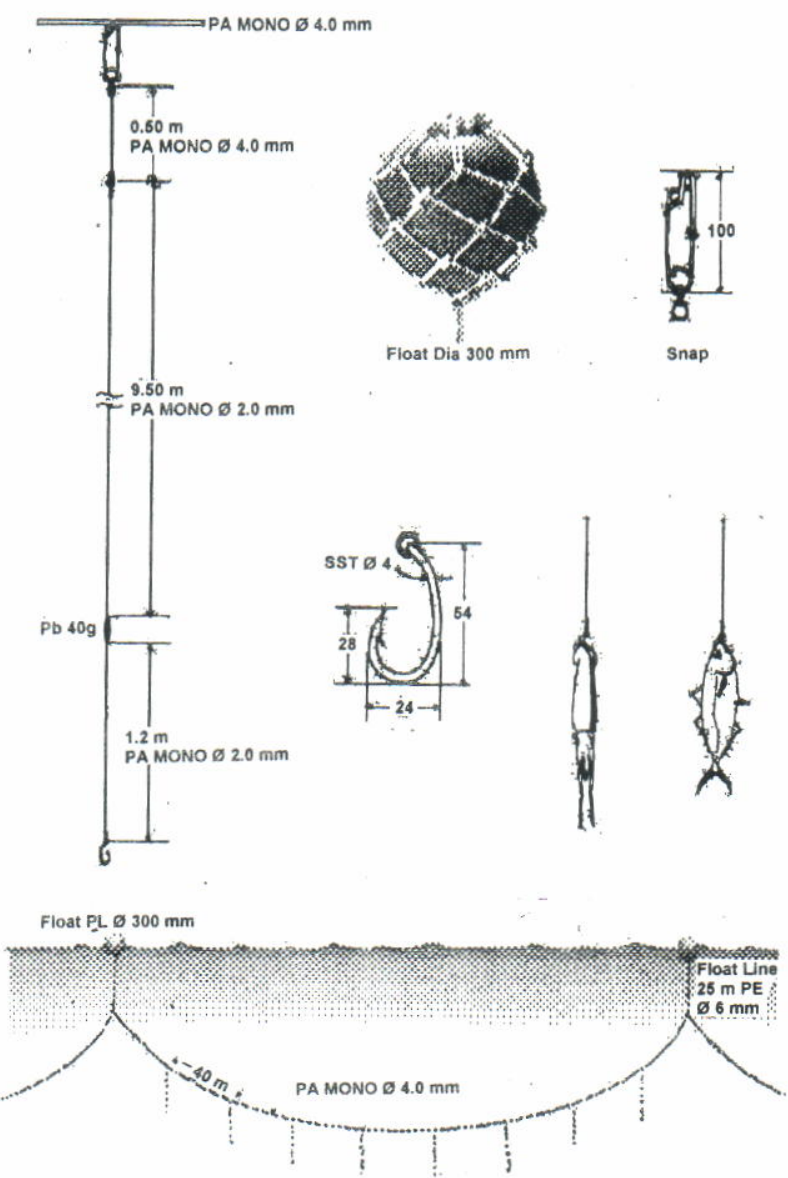

Gambar 1. Konstruksi tuna long line dalam 1 basket. Sumber/Sources: SEAFDEC/TD (2003) 


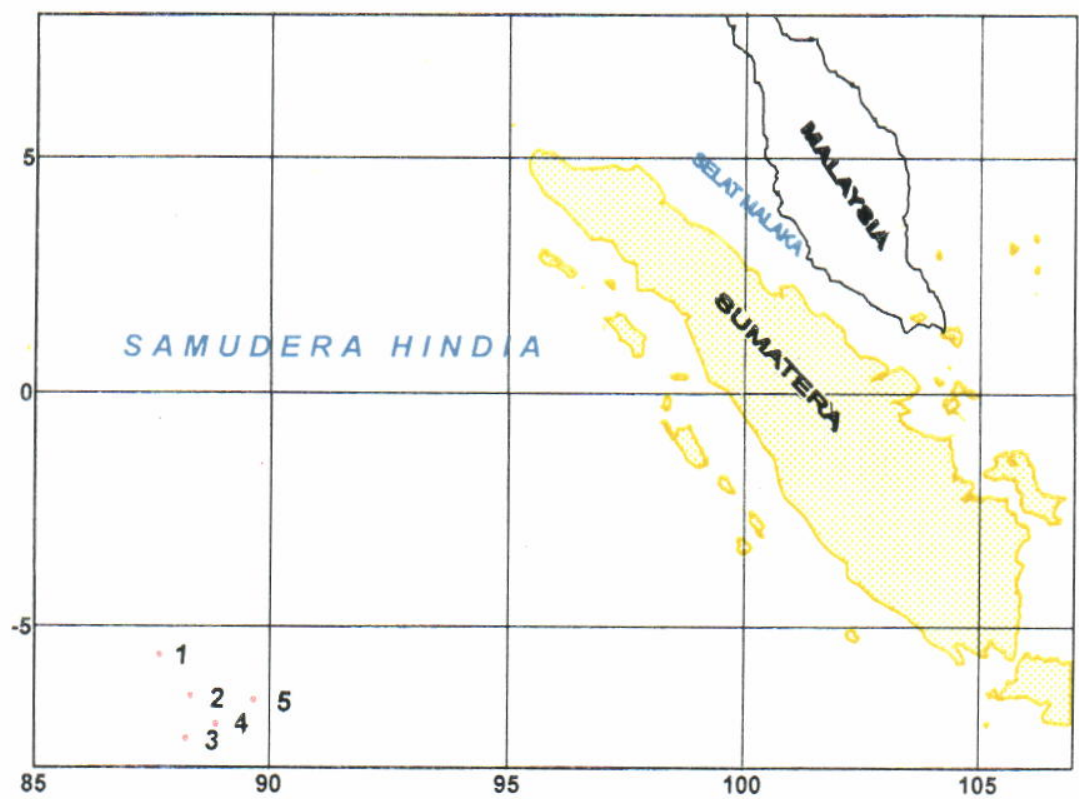

Gambar 2. Daerah penangkapan ikan dengan tuna long line di perairan barat Sumatera.

132 sampai dengan $142 \mathrm{~cm}$. Pada Tabel 1 dapat dilihat jumlah hasil tangkapan dan hook rate masing-masing spesies setiap kali tawur.

Hasil tangkapan sampingan terbagi 2 , yaitu jenis ikan yang memiliki nilai ekonomis tinggi dan tidak memiliki nilai ekonomis (Beverly et al., 2003). Hasil tangkapan sampingan yang memiliki nilai ekonomis antara lain sailfish (famili Istiophoridae), wahoo (famili Scombridae), common dolphinfish (famili Coryphaenidae), shark (famili Carcharhinidae dan Pseudocarchariidae), dan escolar (famili Gempylidae). Sedangkan yang tidak memiliki nilai ekonomis antara lain stingray (famili Dasyatidae), snake mackerel (famili Gempylidae), dan lancetfish (famili Alepisauridae) (Tabel 2). Komposisi dari beberapa jenis ikan sebagai target penangkapan dan hasil tangkapan sampingan dikemukakan pada Gambar 3 dan 4.

Hasil tangkapan sampingan didominasi oleh jenis Lepidocybium flavobrunneum (escolar) 16 ekor $(20,78 \%)$, kemudian disusul oleh Alepisaurus ferox (lancetfish) 9 ekor (11,69\%) dan Prionace glauca (blue shark) 7 ekor $(9,09 \%)$.

\section{TUNA PURSE SEINE}

\section{Deskripsi Alat Tangkap}

Jaring tuna purse seine milik MV. SEAFDEC mempunyai panjang $1.267 \mathrm{~m}$ dan dalam $231 \mathrm{~m}$. Deskripsi alat tangkap terdiri atas pelampung

Tabel 1. Jumlah hasil tangkapan dan laju tangkap yellowfin tuna, bigeye tuna, dan swordfish setiap kali tawur

\begin{tabular}{|c|c|c|c|c|c|c|c|c|c|c|c|}
\hline \multirow[b]{2}{*}{ soting } & \multicolumn{2}{|c|}{ Posist } & \multirow[b]{2}{*}{$\begin{array}{l}\text { fumian } \\
\text { pancing } \\
\text { (buan) }\end{array}$} & \multicolumn{2}{|c|}{ Yellowino luna } & \multicolumn{2}{|c|}{ grgeye luna } & \multicolumn{2}{|c|}{ Swordfish. } & \multicolumn{2}{|c|}{ By catch } \\
\hline & Setring & Haulfng & & $\begin{array}{l}\text { Juman } \\
\text { (exor) }\end{array}$ & $H R$ & Jumlah & HR & Jumian & HR & $\begin{array}{l}\text { Jumla } \\
\text { holor) }\end{array}$ & HR \\
\hline 1 & $\begin{array}{l}05^{\circ} 411^{\prime} 81 \mathrm{~S} \\
87^{\circ} 50^{\prime} 37 \mathrm{E}\end{array}$ & $\begin{array}{l}05^{\circ} 35^{\prime} 30 \mathrm{~S} \\
87^{\circ} 42^{\prime} 07 \mathrm{E}\end{array}$ & 521 & - & - & - & - & 4 & 0,77 & 17 & 3,26 \\
\hline 2 & $\begin{array}{l}06^{\circ} 33^{\prime} 80 \mathrm{~S} \\
88^{\circ} 32^{\prime} 01 \mathrm{E}\end{array}$ & $\begin{array}{l}06^{\circ} 25^{\prime} 6 \mathrm{~S} \\
88^{\circ} 26^{\prime} 1 \mathrm{E}\end{array}$ & .525 & - & - & - & - & 4 & 0,76 & 9 & 1,71 \\
\hline 3 & $\begin{array}{l}07^{\circ} 28^{\prime} 7 \mathrm{~S} \\
88^{\circ} 27^{\prime} 4 \mathrm{E}\end{array}$ & $\begin{array}{l}07^{\circ} 30^{\prime} 3 \mathrm{~S} \\
88^{\circ} 12^{\prime} 5 \mathrm{E}\end{array}$ & 511 & - & - & 4 & 0,78 & 3 & 0,59 & 8 & 1,57 \\
\hline 4 & $\begin{array}{l}07^{\circ} 09^{\prime} 0 \mathrm{~S} \\
89^{\circ} 05^{\prime} 7 \mathrm{E}\end{array}$ & $\begin{array}{l}07^{\circ} 06^{\prime} 7 \mathrm{~S} \\
88^{\circ} 52^{\prime} 0 \mathrm{E}\end{array}$ & 537 & 1 & 0,19 & 4 & 0,74 & 3 & 0,56 & 7 & 1,30 \\
\hline 5 & $\begin{array}{l}06^{\circ} 36^{\prime} 3 \mathrm{~S} \\
89^{\circ} 53^{\prime} 3 \mathrm{E}\end{array}$ & $\begin{array}{l}06^{\circ} 35^{\prime} 0 \mathrm{~S} \\
89^{\circ} 38^{\prime} 0 \mathrm{E}\end{array}$ & 529 & 2 & 0,38 & 1 & 0,19 & 2 & 0,38 & 8 & 1,51 \\
\hline \multicolumn{3}{|c|}{ Total } & 2623 & 3 & 0,11 & 9 & 0,34 & 16 & 0,61 & 49 & 1,87 \\
\hline
\end{tabular}


Tabel 2. Ikan hasil tangkapan sampingan tuna long line di perairan barat Sumatera pada bulan Desember 2004

\begin{tabular}{|c|c|c|c|c|}
\hline No. & Spesies & Famili: & $\begin{array}{l}\text { Jumlah } \\
\text { (ekor) }\end{array}$ & $\%$ \\
\hline 1 & Dasyatis sp. (Stingray) & Dasyatidae & 2 & 4,08 \\
\hline 2 & Lepidocybium flavobrunneum (Escolar) & Gempylidae & 16 & 32,65 \\
\hline 3 & Gempylus serpens (Snake mackerel) & Gempylidae & 1 & 2,04 \\
\hline 4 & Ruvettus pretiosus (Oilfish) & Gempylidae & 2 & 4,08 \\
\hline 5 & Carcharhinus longimanus (Oceanic white tip shark) & Carcharhinidae & 2 & 4,08 \\
\hline 6 & Carcharhinus falciformis (Silky shark) & Carcharhinidae & 3 & 6,12 \\
\hline 7 & Prionace glauca (Blue shark) & Carcharhinidae & 7 & 14,29 \\
\hline 8 & Pseudocarcharias kamoharai (Crocodile shark) & Pseudocarchariidae & 1 & 2,04 \\
\hline 9 & Alepisaurus ferox (Lancetfish) & Alepisauridae & 9 & 18,37 \\
\hline 10 & Acanthocybium solandri (Wahoo) & Scombridae & 2 & 4,08 \\
\hline 11 & Istiophorus platypterus (Sailfish) & Istiophoridae & 1 & 2,04 \\
\hline 12 & Coryphaena hippurus (Common dolphinfish) & Coryphaenidae & 3 & 6,12 \\
\hline \multicolumn{2}{|r|}{ Total } & & 49 & 100 \\
\hline
\end{tabular}
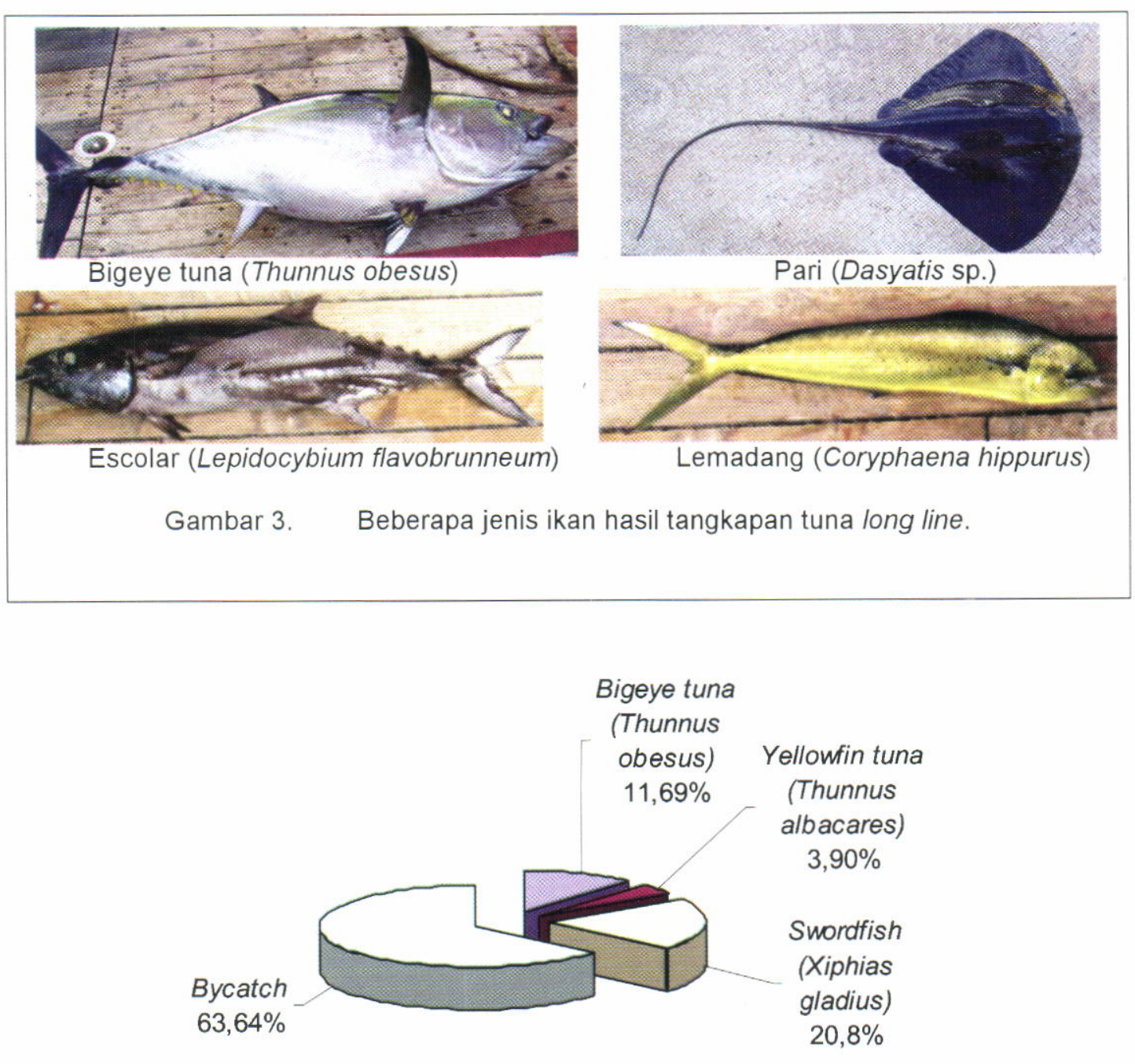

Gambar 4. Komposisi hasil tangkapan tuna long line. 


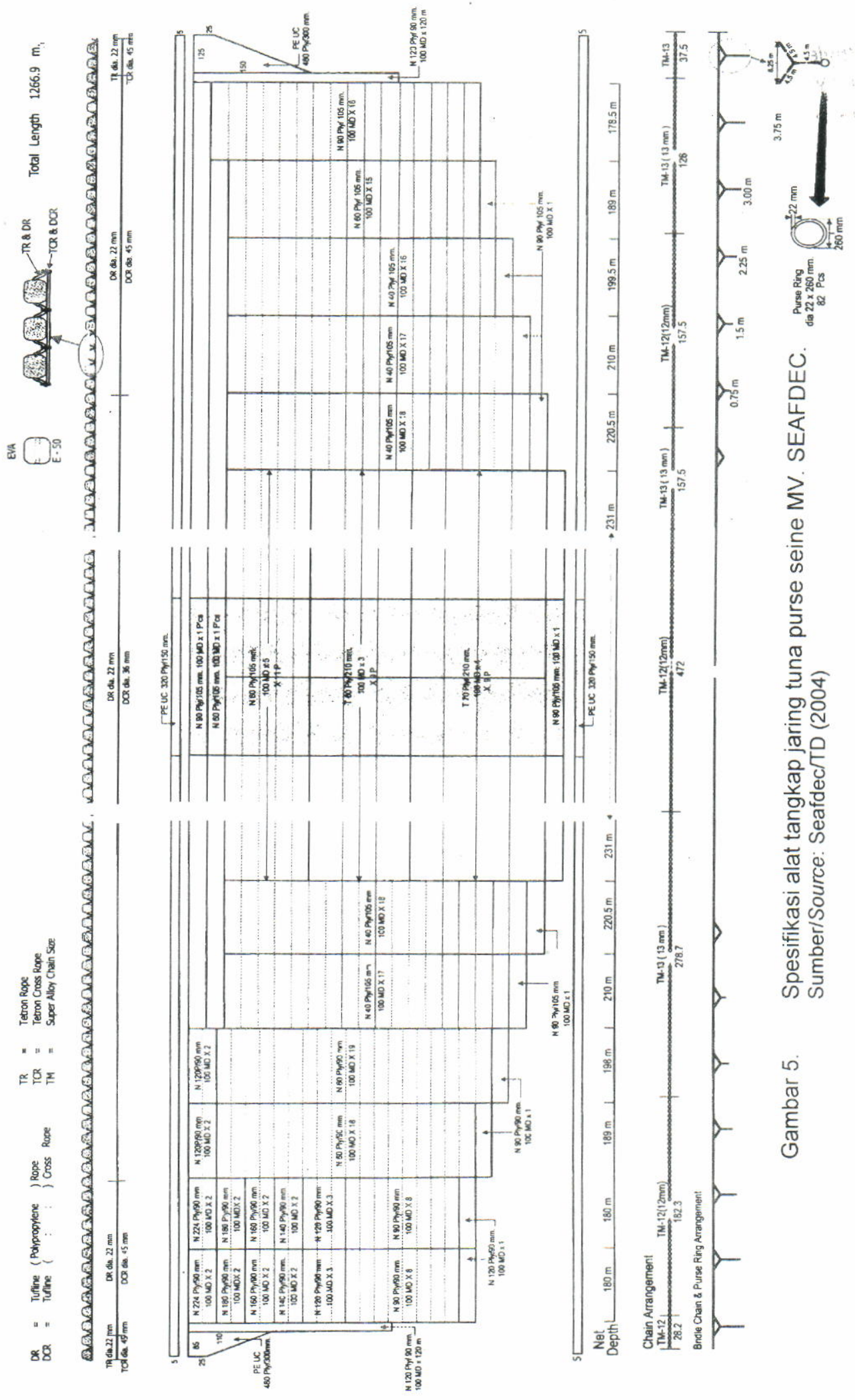


(float), tali pelampung (float line), tali ris atas, rantai pemberat, dan cincin (ring). Pelampung terbuat dari Ethylene Vinyl Acetate (EVA) E-500 dengan bouyancy $5.000 \mathrm{~g}$ dan berjumlah 4.200 buah. Tali pelampung terbuat dari polypropilene dengan diameter $22 \mathrm{~mm}$. Tali ria atas juga terbuat dari polypropilene dengan diameter $45 \mathrm{~mm}$. Rantai pemberat terbuat dari besi alloy ukuran 11 sampai dengan $13 \mathrm{~mm}$ dengan diameter $45 \mathrm{~mm}$. Cincin terbuat dari galvanise iron $22 \mathrm{~mm}$ dengan diameter $260 \mathrm{~mm}$.

Kantong terbuat dari bahan PA 40 sampai dengan 224 ply mesh size $90 \mathrm{~mm}$ dengan suporting bunt PA 40 sampai dengan 60 ply mesh size $90 \mathrm{~mm}$. Main part terbuat dari 2 material yaitu PA 40 sampai dengan 60 ply mesh size $90 \mathrm{~mm}$ dan PES 60 ply mesh size $210 \mathrm{~mm}$. Sayap (wings) terbuat dari bahan PA 40 sampai dengan 60 ply mesh size $105 \mathrm{~mm}$. Selvedge atas dan bawah terbuat dari poly ethylene ultra cross 350 ply mesh size $150 \mathrm{~mm}$. Tali kolor (purse line) terbuat dari bahan dry wire diameter 19 sampai dengan 24 $\mathrm{mm}$ dengan total length $2.000 \mathrm{~m}$. Towing line terbuat dari dry wire diameter $19 \mathrm{~mm}$ dengan total length $1.000 \mathrm{~m}$ (Gambar 5).

Operasi penangkapan dilakukan 5 kali dengan menggunakan sistem 2 kapal (two boat system). Pengoperasian dilakukan pada pagi hari sekitar pukul $04 .^{30}$ dan selesai sekitar pukul $10 .^{00}$. Sebagai alat bantu penangkapan digunakan rumpon (FADs) yang bertujuan untuk memikat ikan untuk berkumpul. Rumpon yang digunakan pada saat pengoperasian berjumlah 5 buah, yaitu
4 buah milik M. V. Nippon Maru (Jepang) dan 1 buah milik M. V. SEAFDEC. Posisi jaring pada saat pengoperasian tuna purse seine dikemukakan pada Gambar 6.

\section{Daerah Penangkapan}

Daerah penangkapan (fishing ground) tuna purse seine terletak pada posisi geografis antara $01^{\circ} 23^{\prime} 6-06^{\circ} 41^{\prime} 5$ LS dan $90^{\circ} 16^{\prime} 9-94^{\circ} 32^{\prime} 6$ BT (Gambar 7).

\section{Komposisi Hasil Tangkapan}

Total hasil tangkapan yang diperoleh sekitar 54 ton. Penebaran jaring ke-1 diperoleh hasil tangkapan 40 ton, ke-2 5 ton, ke-3 5 ton, ke-4 4 ton, dan ke-5 tidak diperoleh hasil tangkapan. Ratarata hasil tangkapan per hauling (catch per haul) 10,8 ton. Pada penebaran jaring ke-5 tidak diperoleh ikan, dikarenakan sewaktu melingkarkan jaring, mesin kapal pelingkar jaring (skiff boat) mengalami kerusakkan sehingga jaring tidak membentuk lingkaran. Akibat kegagalan pelingkaran tersebut, jaring mengalami kerusakan dan banyak ikan yang melarikan diri.

Komposisi hasil tangkapan terdiri atas cakalang atau skipjack tuna (Katsuwonus pelamis), tuna mata besar atau bigeye tuna (Thunnus obesus), dan madidihang atau yellowfin tuna (Thunnus albacares) (Tabel 3). Hasil tangkapan sampingan (bycatch) terdiri atas famili Scombridae (wahoo), famili Coryphaenidae (common dolphinfish), famili Carcharhinidae (shark), famili Dasyatidae (stingray), famili Carangidae (scad dan rainbow

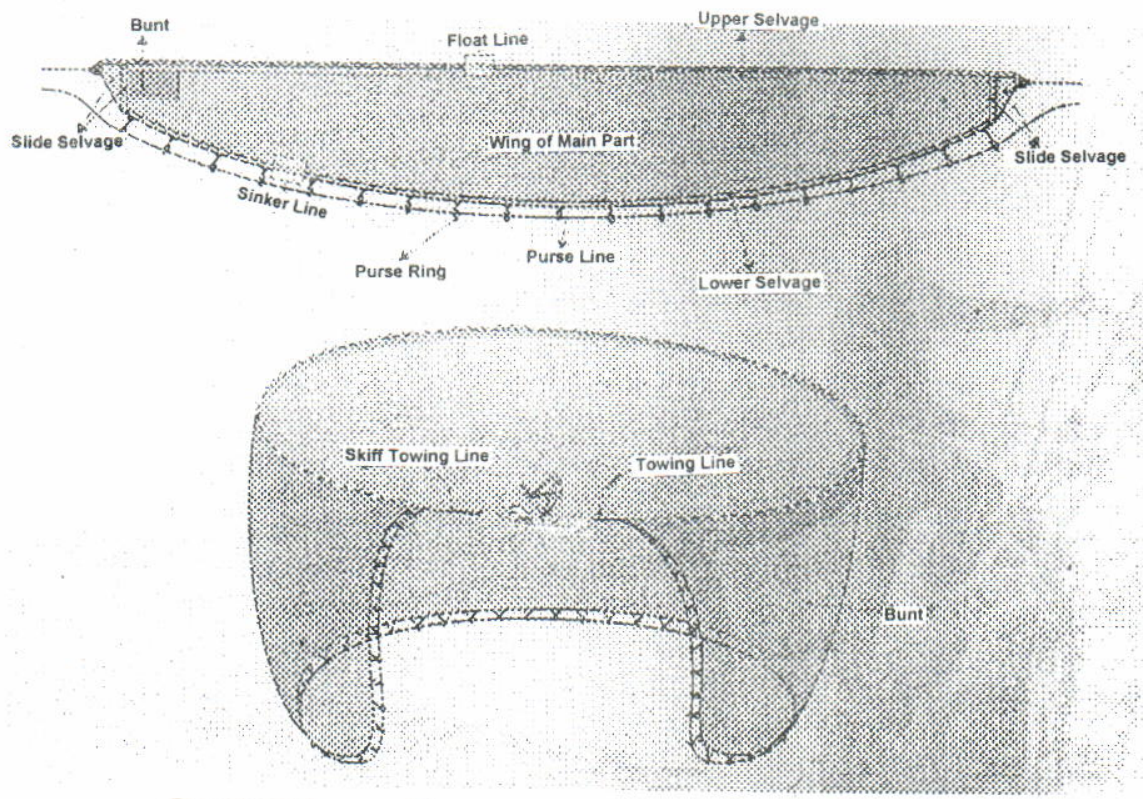

Gambar 6. Tuna purse seine ketika dioperasikan. Sumber/Sources: SEAFDEC/TD (2004) 


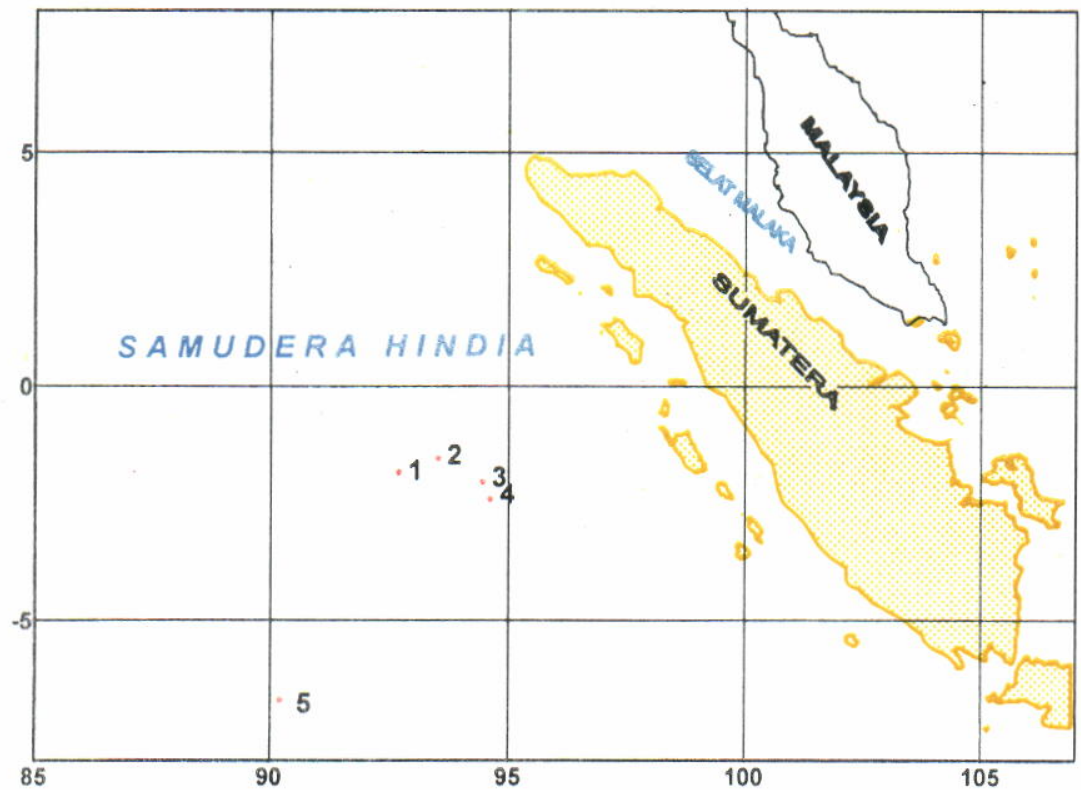

Gambar 7. Daerah penangkapan ikan dengan tuna purse seine di perairan barat Sumatera pada bulan Desember 2004.

Tabel 3. Pengambilan contoh hasil tangkapan tuna purse seine setiap kali tawur

\begin{tabular}{|c|c|c|c|c|c|c|c|c|c|c|}
\hline \multirow{2}{*}{$\begin{array}{l}\text { No: } \\
\text { Setring }\end{array}$} & \multirow{2}{*}{$\begin{array}{l}\text { Posist } \\
\text { Setting }\end{array}$} & \multicolumn{2}{|c|}{$\begin{array}{l}\text { Yellowfin } \\
\text { Tuna }\end{array}$} & \multicolumn{2}{|c|}{ Blgeye Tuna } & \multicolumn{2}{|c|}{ Skipjack tuna } & \multicolumn{2}{|c|}{ Bycatch } & \multirow{2}{*}{$\begin{array}{l}\text { Total } \\
\text { (ekor) }\end{array}$} \\
\hline & & $\begin{array}{l}\text { Jumlah } \\
\text { (ekor) }\end{array}$ & $\%$ & $\begin{array}{l}\text { Jumlah } \\
\text { (ekor) }\end{array}$ & $\%$ & $\begin{array}{l}\text { Jumiah } \\
\text { (ekor) }\end{array}$ & $\%$ & $\begin{array}{l}\text { Jumlah } \\
\text { (ekor) }\end{array}$ & $\%$ & \\
\hline 1 & $\begin{array}{l}01^{\circ} 43^{\prime} 2 \mathrm{~S} \\
92^{\circ} 36^{\prime} 5 \mathrm{E}\end{array}$ & 26 & 6,09 & 67 & 15,69 & 315 & 73,77 & 19 & 4,45 & 427 \\
\hline 2 & $\begin{array}{l}01^{\circ} 23^{\prime} 6 \mathrm{~S} \\
93^{\circ} 25^{\prime} 2 \mathrm{E}\end{array}$ & 41 & 8,76 & 75 & 16,03 & 302 & 64,53 & 50 & 10,68 & 468 \\
\hline 3 & $\begin{array}{l}01^{\circ} 51^{\prime} 8 \mathrm{~S} \\
94^{\circ} 22^{\prime} 3 \mathrm{E}\end{array}$ & 41 & 5,02 & 8 & 0,98 & 737 & 90,32 & 30 & 3,68 & 816 \\
\hline 4 & $\begin{array}{l}02^{\circ} 13^{\prime} 5 \mathrm{~S} \\
94^{\circ} 32^{\prime} 6 \mathrm{E}\end{array}$ & 55 & 7,76 & 19 & 2,68 & 613 & 86,46 & 22 & 3,10 & 709 \\
\hline 5 & $\begin{array}{l}06^{\circ} 41^{\prime} 5 \mathrm{~S} \\
90^{\circ} 16^{\prime} 9 \mathrm{E}\end{array}$ & - & - & - & - & - & - & - & - & - \\
\hline
\end{tabular}

Tabel 4. Hasil tangkapan sampingan tuna purse seine

\begin{tabular}{|c|c|c|c|c|}
\hline No: & Spesies & Famili & $\begin{array}{l}\text { Jumlah } \\
\text { (ekor) }\end{array}$ & $\%$ \\
\hline 1 & Acanthocybium solandri (Wahoo) & Scombridae & 4 & 3,31 \\
\hline 2 & Coryphaena hippurus (Common dolphinfish) & Coryphaenidae & 2 & 1,65 \\
\hline 3 & Carcharhinus falciformis (Silky shark) & Carcharhinidae & 3 & 2,48 \\
\hline 4 & Dasyatis sp. (Stingray) & Dasyatidae & 1 & 0,83 \\
\hline 5 & Elagatis bipinnulata (Rainbow runner) & Carangidae & 29 & 23,97 \\
\hline 6 & Decapterus sp. (Șcad) & Carangidae & 1 & 0,83 \\
\hline 7 & Aluterus monoceros (Unicorn leatherjacket) & Monacanthidae & 1 & 0,83 \\
\hline 8 & Aluterus scriptus (Scrawled filefish) & Monacanthidae & 2. & 1,65 \\
\hline 9 & Canthidermis maculatus (Triggerfish) & Balistidae & 71 & 58,68 \\
\hline 10 & Kyphosus sp. (Seachub) & Kyphosidae & 2 & 1,65 \\
\hline 11 & Makaira mazara (Blue marlin) & Istiophoridae & 1 & 0,83 \\
\hline 12 & Platax sp. (Batfish) & Ephippidae & 2 & 1,65 \\
\hline 13 & Lobotes surinamensis (Atlantic tripletail) & Lobotidae & 1 & 0,83 \\
\hline 14 & Sea turtle & - & 1 & 0,83 \\
\hline \multicolumn{3}{|c|}{ Total } & 121 & 100 \\
\hline
\end{tabular}


runner), famili Monacanthidae (unicorn leatherjacket dan scrawled filefish), famili Istiophoridae (Indo Pasific blue marlin), famili Ephippidae (batfish), famili Lobotidae (Atlantic tripletail), famili Balistidae (triggerfish), dan famili Kyphosidae (seachub) (Tabel 4).

Secara keseluruhan, komposisi hasil tangkapan didominasi oleh skipjack tuna $81,28 \%$, kemudian diikuti bigeye tuna $6,98 \%$, yellowfin tuna $6,74 \%$, dan ikan lain (bycatch) $5,00 \%$ (Gambar 8).
Beberapa jenis ikan yang tertangkap selama pengoperasian tuna purse seine di perairan barat Sumatera dikemukakan pada Gambar 9.

Pengamatan aspek biologi dari hasil pengambilan contoh diperoleh kisaran panjang cagak (FL) skipjack tuna antara 27 sampai dengan $61 \mathrm{~cm}$ dengan modus $41 \mathrm{~cm}$, yellowfin tuna antara 30 sampai dengan $137 \mathrm{~cm}$ dengan modus $45 \mathrm{~cm}$ dan bigeye tuna antara 34 sampai dengan $71 \mathrm{~cm}$ dengan modus $51 \mathrm{~cm}$ (Gambar 10).

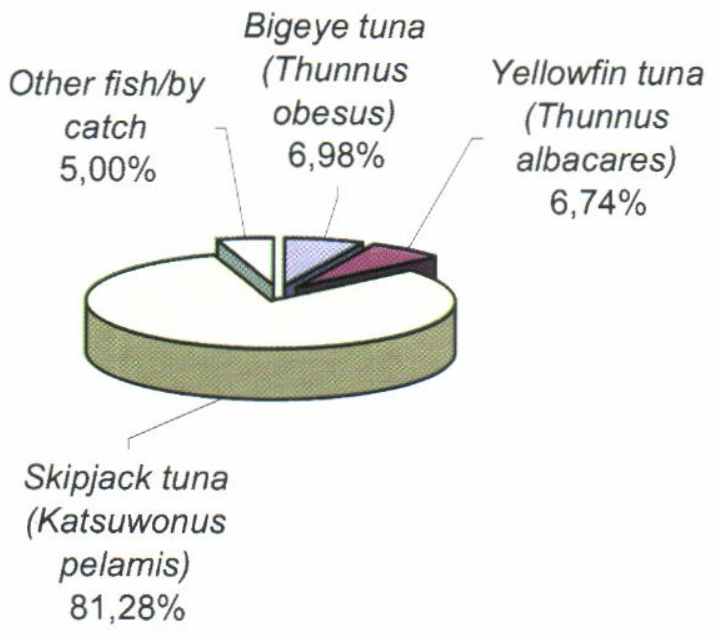

Gambar 8. Komposisi hasil tangkapan tuna purse seine.

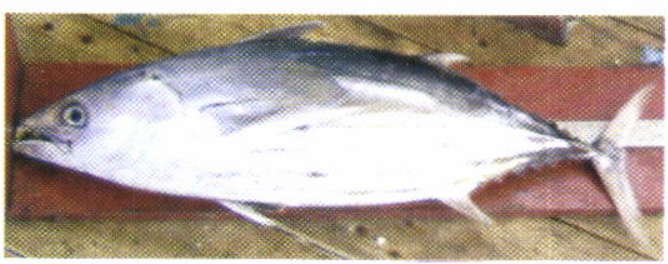

Skipjack tuna (Katsuwonus pelamis)

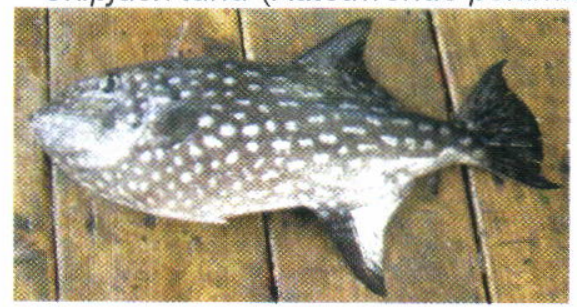

Triggerfish (Canthidermis maculatus)

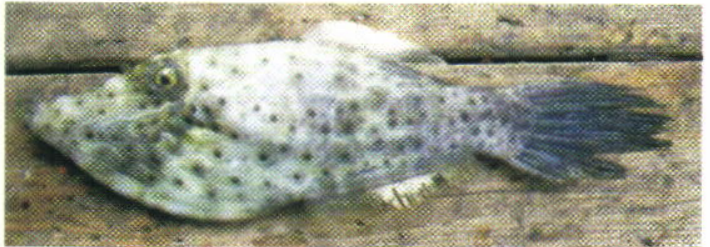

Scrawled filefish (Aluterus scriptus)

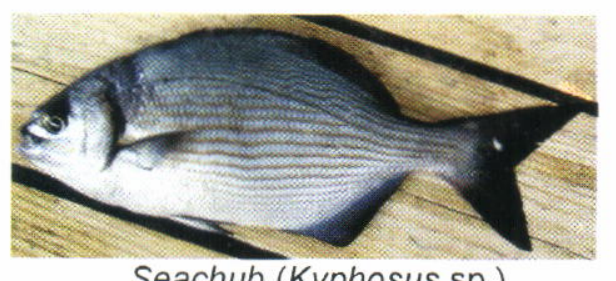

Seachub (Kyphosus sp.)

Gambar 9. Beberapa jenis ikan hasil tangkapan tuna purse seine.

\section{PERCOBAAN PENANDAAN TUNA (TUNA TAGGING)}

Penandaan (tagging) dilakukan terhadap bigeye tuna dan yellowfin tuna yang tertangkap. Tujuan dari penandaan ini adalah untuk mengetahui migrasi dari ikan-ikan tuna yang tertangkap di perairan Samudera Hindia sebelah barat Indonesia. Ikan tuna yang diberi tanda mempunyai ukuran panjang (FL) antara 36 sampai dengan $63 \mathrm{~cm}$ dan berjumlah 452 ekor (121 ekor bigeye tuna dan 331 ekor yellowfin tuna). 

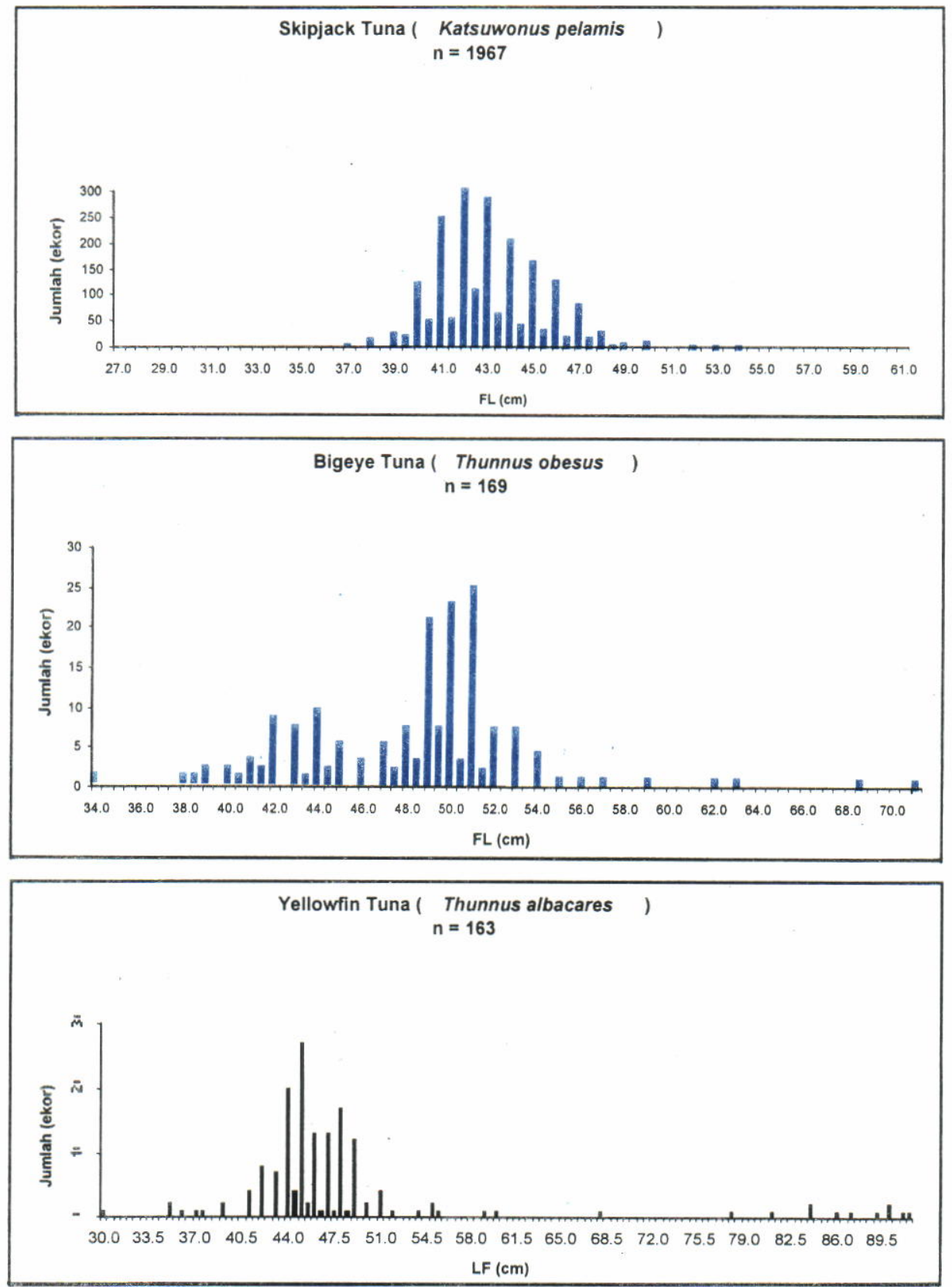

Gambar 10. Distribusi length frequency skipjack tuna, bigeye tuna, dan yellowfin tuna hasil tangkapan tuna purse seine di perairan barat Sumatera pada bulan Desember 2004.

Panjang bigeye tuna yang paling banyak diberi tanda berukuran $51 \mathrm{~cm}$ dengan jumlah 19 ekor, sedangkan yellowfin tuna berukuran $45 \mathrm{~cm}$ dengan jumlah 62 ekor. Distribusi ukuran panjang dari bigeye tuna dan yellowfin tuna yang diberi tanda dapat dilihat pada Gambar 11.

\section{FISH AGGREGATING DEVICES}

Fish aggregating devices atau lebih dikenal dengan nama rumpon laut dalam atau payao oleh kalangan nelayan dianggap sebagai alat bantu penangkapan. Alat ini berfungsi sebagai tempat berkumpul ikan yang merupakan bagian penting dalam operasi penangkapan dengan purse seine.

Ada 2 tipe rumpon yang dikenal yaitu anchored payao yang dipasang menetap pada perairan dan drift payao yang bergerak bebas mengikuti pergerakan arus. Pada percobaan ini digunakan drift payao dengan alat bantu radio bouy. Rakit bambu yang digunakan berdiameter 12 sampai dengan $15 \mathrm{~cm}$ dengan ukuran panjang rakit $3,4 \mathrm{~m}$ dan lebar $2,6 \mathrm{~m}$. Bingkai rumpon (frame) terbuat dari pipa besi berdiameter 1,5 sampai dengan 2 


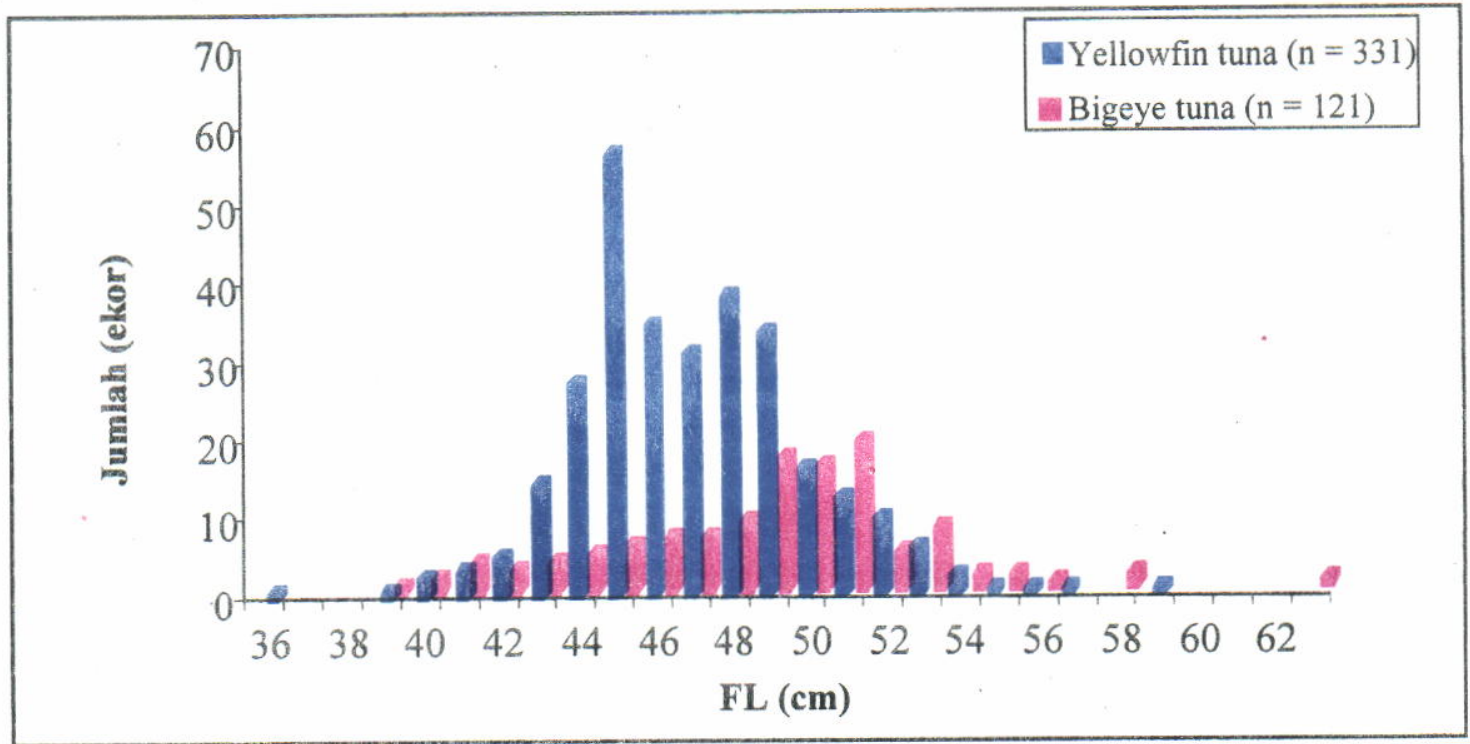

Gambar 11. Distribusi ukuran panjang bigeye tuna dan yellowfin tuna yang diberi tanda.
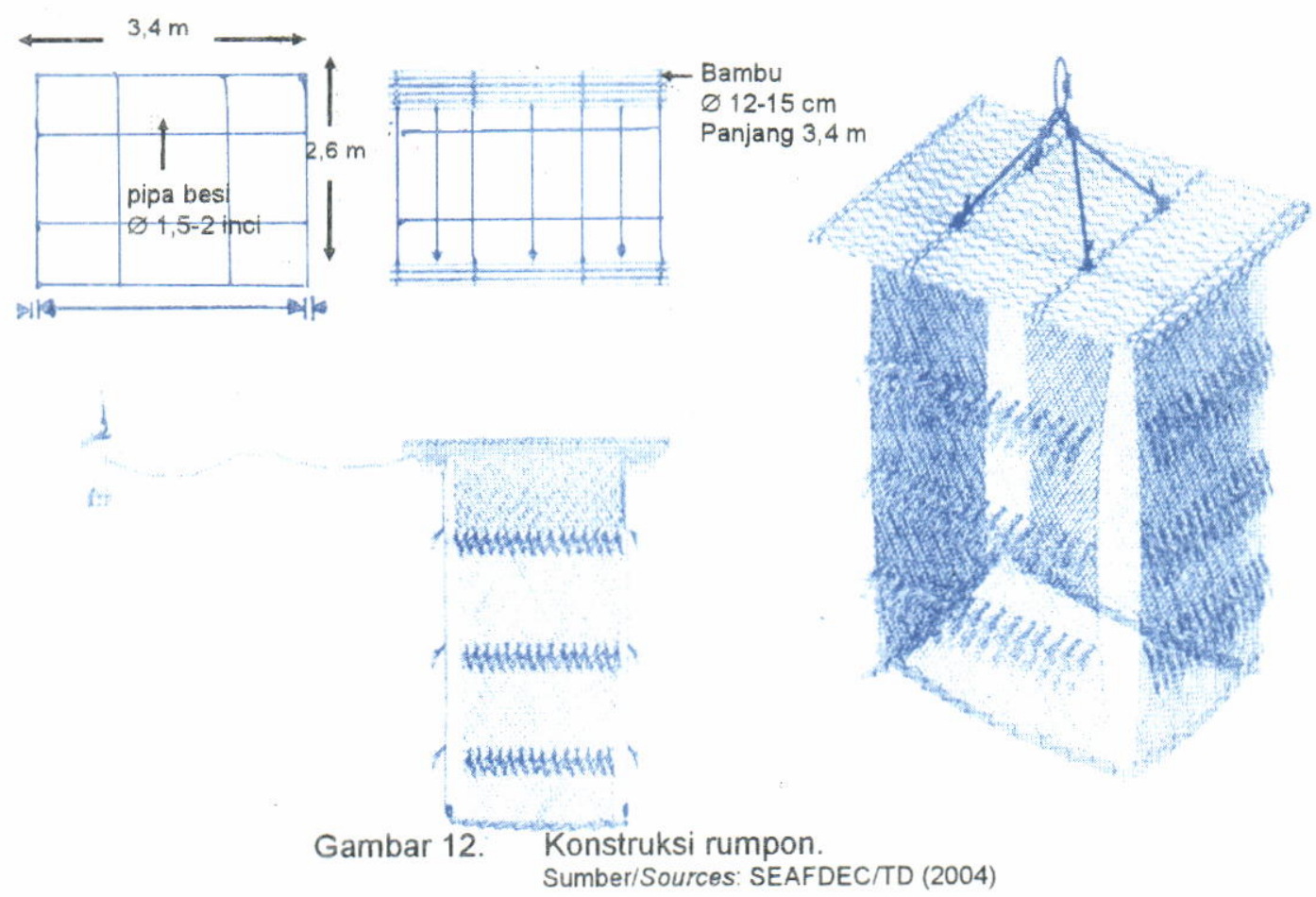

inci dan menggunakan 8 buah pelampung purse seine E-500. Sebagai pemikat ikan digunakan jaring dengan ukuran mata jaring (mesh size) 11 $\mathrm{cm}$ dan ukuran panjang atau dalam antara 8 sampai dengan $10 \mathrm{~m}$. Pemberat terbuat dari semen 4 buah dan dipasang pada tiap sudut jaring dengan bobot masing-masing $5 \mathrm{~kg}$. Konstruksi rumpon dapat dilihat pada Gambar 12.

\section{KESIMPULAN}

1. Hasil tangkapan tuna long line didominasi oleh swordfish $(20,78 \%)$ dengan hook rate 0,61 , diikuti oleh bigeye tuna (11,69\%) dengan hook rate 0,34 dan yellowfin tuna $(3,90 \%)$ dengan hook rate 0,11 .

2. Hasil tangkapan tuna purse seine didominasi oleh skipjack tuna $81,28 \%$, diikuti oleh bigeye tuna $6,98 \%$, yellowfin tuna $6,74 \%$, dan ikan lain (by catch) $5,00 \%$.

3. Kisaran panjang cagak (FL) swordfish yang tertangkap dengan tuna long line antara 98 sampai dengan $209 \mathrm{~cm}$, bigeye tuna antara 105 sampai dengan $141,5 \mathrm{~cm}$ dan yellowfin 
tuna antara 132 sampai dengan $142 \mathrm{~cm}$, sedangkan skipjack tuna yang tertangkap dengan tuna purse seine antara 27 sampai dengan $61 \mathrm{~cm}$, yellowfin tuna antara 30 sampai dengan $137 \mathrm{~cm}$ dan bigeye tuna antara 34 sampai dengan $71 \mathrm{~cm}$.

\section{DAFTAR PUSTAKA}

Beverly, S., L. Chapman, \& W. Sokimi. 2003. Horizontal long line fishing methods and techniques. A Manual for Fishermen. Multipress. Noumea. New Caledonia.

Diniah, M. Ali Yahya, S. Pujiyati, Parwinia, S. Effendy, M. Hatta, M. Sabri, Rusyadi, \& A. Farhan. 2001. Pemanfaatan sumber daya tuna cakalang secara terpadu. Makalah Falsafah Sains. Program Pasca Sarjana. Institut Pertanian Bogor. Bogor.
Gafa, B., K. Wagiyo, \& B. Nugraha. 2004. Hubungan antara suhu dan kedalaman mata pancing terhadap hasil tangkapan bigeye tuna (Thunnus obesus) dan yellowfin tuna (Thunnus albacares) dengan tuna long line di perairan Laut Banda dan sekitar. Prosiding Hasil-Hasil Riset. Pusat Riset Perikanan Tangkap. Badan Riset Kelautan dan Perikanan. Departemen Kelautan dan Perikanan. Jakarta.

SEAFDEC/TD. 2003. Pelagic long line. Handbook for Pelagic Longliners. Training Department or Southeast Asian Fisheries Development Center. Samutprakan. 52 p.

SEAFDEC/TD. 2004. Tuna purse seine. Handbook for Tuna Purse Seine Fishermen. Training Department or Southeast Asian Fisheries Development Center. Samutprakan. 50 p. 
